\section{Computer-assisted telephone interviewing (CATI): using the telephone for obtaining information on reproductive health}

\author{
Computer-assisted Telephone Interviewing (CATI): \\ usando telefone para a obtenção de informações \\ sobre saúde reprodutiva
}

\author{
1 Faculdade de Ciências \\ Médicas, Universidade \\ Estadual de Campinas, \\ Campinas, Brasil. \\ 2 Centro de Pesquisas em \\ Saúde Reprodutiva de \\ Campinas, Campinas, Brasil. \\ Correspondence \\ J. G. Cecatti \\ Faculdade de Ciências \\ Médicas, Universidade \\ Estadual de Campinas. \\ Rua Alexander Fleming 101, \\ Campinas, $S P$ \\ 13083-884, Brasil. \\ cecatti@unicamp.br
}

\begin{abstract}
The objective of this study was to evaluate the feasibility of using computer assisted telephone interviewing (CATI) as a method for obtaining information on reproductive health in Brazil. A total of 998 eligible women for the study were selected to answer a questionnaire through computer- assisted telephone interviewing undertaken by trained interviewers. The outcomes of each telephone contact attempt were described. Differences between groups were assessed using the $\chi^{2}$ test. Phone contact was made in $60.3 \%$ of the attempts and $57.5 \%$ of the interviews were completed. The success rate improved with the decrease in time from hospitalization to interview and with the higher numbers of telephones available. A total of 2,170 calls were made, comprising of one to sixteen attempts per woman. The majority of situations where extra calls were necessary were due to the number being busy or to the fact that the woman was not available at the time of the call. CATI can prove be a valuable procedure for obtaining information on reproductive health among Brazilian women, particularly for relatively recent events and when more than one alternative telephone number is available.
\end{abstract}

Interviews; Telephone; Reproductive Medicine
Jose Guilherme Cecatti 1,2

Rodrigo P. S. Camargo 1

Rodolfo Carvalho Pacagnella 1

Thaís Giavarotti 1

João Paulo Souza 1

Mary Angela Parpinelli 1,2

Maria José Duarte Osis 1,2

\section{Background}

In the past, much demographic and health research was carried out on a one-to-one basis resulting in a heavy work effort and high costs. Since the beginning of the last century, the telephone has been increasingly used for research purposes and this research method has been subject to a number of improvements resulting in cost reduction benefits. The development of computer-assisted telephone interviewing (CATI) with a structured and digitally-recorded questionnaire also allows the interviewer to take better custody of the interview. Telephone interviewing has now become a common method in health research 1,2 .

Recent research carried out by an Australian group compared recall of parents' highest level of education in telephone and face-to-face surveys and concluded that the survey mode did not appear to influence the results ${ }^{3}$. Other studies have investigated the concordance between telephone and face-to-face interviewing for obtaining information on psychiatric disorders and, although the authors found that telephone interviewing generally showed a good level of agreement with face-to-face clinical interviews, there can be a discordance between the methods, as the telephone method can even under- or over-estimate the diagnostic relative to clinical face-to-face interview 4,5. Nevertheless, there are consistent data on similarities of answers obtained by tele- 
phone and face-to-face interview, which encourage the use of the telephone method 6 .

One problem of telephone interviews for population surveys is the possibility of selection bias in countries with poor telephone coverage $7,8,9$. In such a context, it is even more difficult to use telephone based research. However, since 2003 there has been an unprecedented access to communications and most of the growth has taken place in the developing world due to mobile phone usage 10 .

In 2008 mobile telephone has achieved the status of a universal technology with four billion subscribers (against 1.3 billion home line telephones). Most of the increase occurred in developing countries which helped to bridge regional divides between urban centers and rural peripheries and reduce the gap in communication technology between high and low income countries 10. In fact, in the recent past, until 2001 Brazil's rate of households with a landline telephone was only $28 \%$, and $59 \%$ of households had at least one telephone available 11. More recently, Brazil reached a penetration rate of 78.5 telephones per 100 in 2008. Those numbers show that it is potentially feasible to carry out this kind of study in middle income countries 12,13.

Therefore, the use of this method in population surveys on maternal health is an alternative to reach broader populations. In maternal health research, the study of maternal morbidity could then theoretically be improved by telephone surveys in such settings. However, there are two different situations concerning the use of telephones in research: when using a probabilistic sample of households with landline or mobile telephones to find somebody with certain characteristics and when tracing a specific subject selected from a database.

The present study addresses information on the feasibility of tracing by telephone women admitted in a tertiary hospital in a developing setting with the purpose of obtaining information on reproductive health.

\section{Methods}

\section{Design}

During a validation study to investigate the ability of a questionnaire to identify women who survived severe complications related to pregnancy and childbirth 14, we performed an analysis of the telephone data collection strategy. This study was carried out in a teaching hospital in São Paulo State, Southeast of Brazil, with women who had been admitted at the maternity ward.
Women with severe complications were identified among those who were admitted to the obstetrical intensive care unit (ICU) of the institution between October 2002 and October 2007. Women who did not present severe complications were identified among those who stayed in the in-patient ward after delivery in the same period as those with maternal morbidity. They were identified in a patient list obtained from the hospital information system. The telephone contact information (household phone, mobile phone, work phone, message phone) was obtained from the medical records.

\section{Questionnaire}

The pre-coded, structured questionnaire was established with 31 simple and directed questions in Brazilian Portuguese that demonstrate an objective response standard. Some questions were linked between them, and depending on the answer obtained in some of the questions, it could eliminate a following block of questions, reducing the questionnaire to up to $55 \%$ of its original scope. It is based on questions that identify the diagnosis of pre-eclampsia/ eclampsia, hemorrhage, infection and jaundice as the main causes of severe maternal morbidity and mortality. It operates at two levels with four key questions, investigating directly the occurrence of complications, and complementary questions aimed to confirm or refute the suggested diagnosis through the key questions.

The development of the questionnaire had prioritized the viability of the use of telephone and computers for the interviews. Therefore, the questions were read directly on the computer screen and the answers were immediately recorded in the system. The digital format of the questionnaire enables the automatic jump of non applied questions according to the prior answer. These steps could guarantee the agility in the conduction of the interviews. Details on this instrument and study are already published elsewhere 14 .

\section{Telephone data collection}

During the period from July through October 2007, the telephone interviews were performed by three trained female interviewers, who received training to reach the eligible women and to carry out the interview. The interviewers were under the supervision of a research assistant skilled in reproductive health teleresearch. All the phone calls were performed at a call center assembled specifically to conduct this kind of research. 
A mixed list including only name and contact information on both categories of women was prepared to keep the interviewers unaware of the actual condition of each woman in this regard. The interviewers received the list provided by the researcher and from that list a contact sheet was completed with the name and the telephone of the next participant.

The interviewer called the given number and asked to talk with the selected woman. If the operator verified that this woman was not reachable on the number dialled, information about her new address and phone number were asked for. When no information could be collected, the electronic white pages of subscribers were accessed, in order to identify some telephone number registered in the name of the particular woman or associated with her given address.

The same process was used when after the first call an announced automatic message informed that the number did not exist or was out of service. When the person contacted in the first call knew the woman, a phone number and/or the address to contact her were requested.

Multiple efforts were made to trace the majority of the women selected for the study, however the protocol established that those women who were unable to be traced via telephone after five unsuccessful attempts should be excluded. Once contact had been made and the women has provided their consent to participate in the study, the protocol allowed as many attempts as necessary to obtain the interview.

Whenever the interviewer spoke with the selected woman, initially she introduced herself, explained why the woman was receiving the call and immediately after that, the woman was asked for consent to record the interview. The woman was asked if she needed more information on the research. If she had accepted to participate in the study the interview was immediately conducted or scheduled for another occasion. All these steps in trying and getting the interview were registered in each individual contact sheet.

The interviews were recorded with the support of software (NextCall; Next Tech Automação Ltda., São Paulo, Brazil) linked to the telephone system. The information obtained was entered concurrently into an integrated database in SPSS (SPSS Inc., Chicago, USA) by the interviewer who was in front of a computer with a headset while doing the interview. The research assistant supervisor checked five percent of the data collected against the voice recording, providing feedbacks to each interviewer regarding errors, on how to go in depth in a specific question, and checking that appropriate corrections were performed in the database. This checking of data quality was conducted concurrently as the interviews were being performed.

\section{Analysis}

First of all, the rate of success in reaching contact and in completing the interview was described. We also performed an analysis of the rates of successes of other variables including length of time between the delivery and the interview, the city of household, and types of telephones available to contact the woman and outcomes of each attempt of phone contact. For statistical analysis of the differences between the groups we used the $\chi^{2}$ test.

\section{Ethical aspects}

This study was developed following approval from the Institutional Review Board. After ethical approval, the hospital information system provided detailed contact information of all women eligible to the study. An informed consent by phone was obtained in audio record before the inclusion of each woman in the study. The study sponsors' played no role in the study design, data collection, analysis, interpretation or report writing.

\section{Results}

There were initially 998 eligible women for the study. A total of 602 women were reached through telephone $(60.3 \%$ of total success rate in reaching contact) and 574 were interviewed (Figure 1). From the total eligible, 396 women could not be reached by telephone, which represents an initial loss of $39.7 \%$, however, 522 women $(52.3 \%$ ) could be traced at the first attempt and 351 (35.1\%) were reached at this moment.

In women with severe maternal morbidity, no significant differences were found in age, parity, marital status and mode of delivery in comparing these characteristics between the interviewed and not interviewed women (data not shown in table). Among the reached women, those lost after the phone contact were due to seven women who refused to participate in the study $(0.7 \%, 3$ with morbidity and 4 without), 14 who were dead at the moment of the interview (all from the morbidity group) and seven cases in which it was not possible to perform the interview after the initial contact $(0.7 \%)$.

The success rate in completing the interview enhanced significantly as the length of time between the index hospital admission and the interview decreased. The success rate was $70.9 \%$ 


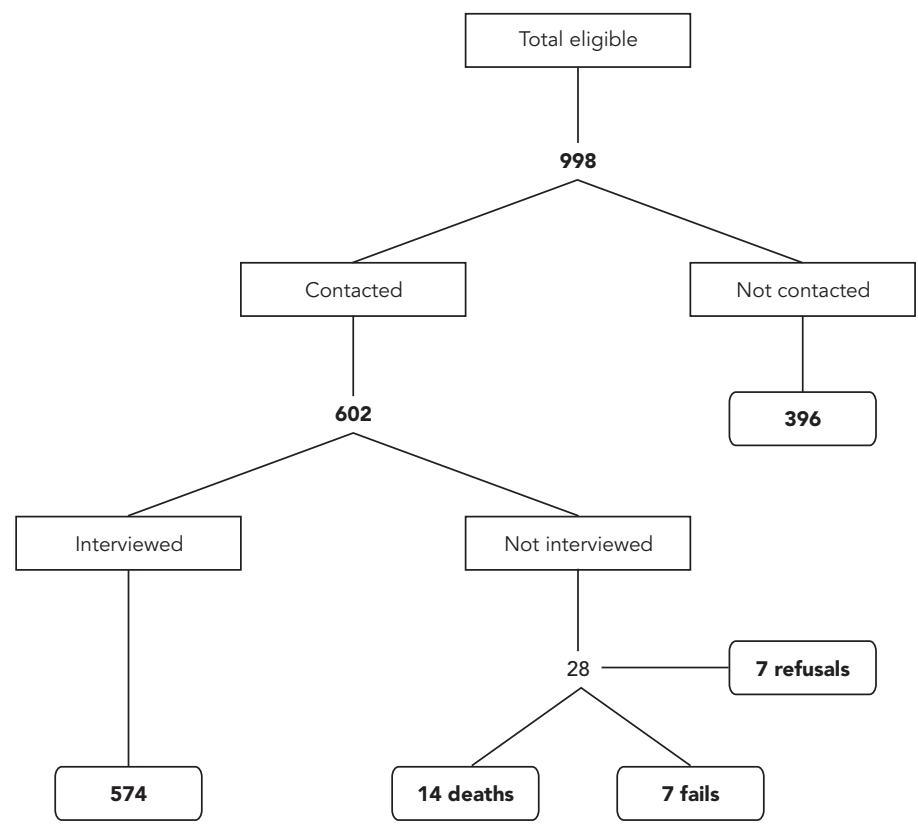

for interviews conducted before one year from the delivery and $35.7 \%$ for interviews performed five years after the delivery. Table 1 shows the success rates of obtaining the interview according to the time between the index hospitalization and the interview, the place of living, and the types of telephones available to contact the woman.

The majority of women interviewed lived in Campinas or in another city in a neighboring area of the São Paulo State. However, the place of residence was not statistically associated with the success in obtaining the interview. When analyzing the type of telephone available for contacting the women, the success rate in completing the interview was $82.7 \%$ for more than one type of telephone, $19.5 \%$ for only a mobile phone and $30.4 \%$ for only home line phone.

Outcomes of each attempt of phone contact are presented in Table 2 . The attempts to contact the women ranged from one to sixteen; "number busy" or "the woman was not available at that moment of the call" accounted for the majority of telephone calls that needed a new call to reach the selected women. At the end of the study a total of 2,170 calls were done (a mean of 2.17 calls for each eligible women), in which 929 had detected a busy number and 347 found the women not available at that moment of the call. There were 542 recorded interviews and 32 not recorded (as per the women's request), accounting for a total of 574 complete interviews, corresponding to $26.5 \%$ of the total of calls.

Among the 155 interviews audited for quality control, only 25 of them (16.1\%) had to change something in the records. Most the corrections were about identification data; in only six records (3.8\%) the supervisor had to update morbidity data.

\section{Discussion}

This study presents an example of a simple and viable method of teleresearch in reproductive health to trace a specific subject selected from a database carried out in Brazil. Although telephone surveys have been used to explore information on health in developed settings for several years 1,15 , there is still some discussion on the validity of telephone surveys for the administration of questionnaires and the mode of contact can interfere in response rates and account for selection bias in public health research. The validity of this method of collecting data needs a 
Success of interview according to time between hospitalization and interview, place of residence and type of telephone.

\begin{tabular}{|c|c|c|c|c|c|}
\hline \multirow[t]{2}{*}{ Condition } & \multicolumn{2}{|c|}{ Interviewed } & \multicolumn{2}{|c|}{ Not interviewed * } & \multirow[t]{2}{*}{ Success rate (\%) } \\
\hline & $\mathbf{n}$ & $\%$ & $\mathbf{n}$ & $\%$ & \\
\hline Year of hospitalization & \multicolumn{5}{|c|}{$\chi^{2}=22.56(p<0.0001)$} \\
\hline 2002 (5 years) & 10 & 1.7 & 18 & 4.5 & 35.7 \\
\hline 2003 (4 years) & 84 & 14.6 & 95 & 23.6 & 46.9 \\
\hline 2004 (3 years) & 106 & 18.5 & 66 & 16.4 & 61.6 \\
\hline 2005 (2 years) & 110 & 19.2 & 89 & 22.1 & 55.3 \\
\hline 2006 (1 year) & 164 & 28.6 & 94 & 23.3 & 63.6 \\
\hline 2007 (< 1 year) & 100 & 17.4 & 41 & 10.2 & 70.9 \\
\hline Place of residence (city) & \multicolumn{5}{|c|}{$\chi^{2}=0.68(p=0.71)$} \\
\hline Campinas & 257 & 44.8 & 179 & 44.4 & 58.9 \\
\hline Other city in São Paulo State & 310 & 54.0 & 205 & 50.9 & 60.2 \\
\hline City in another state & 7 & 1.2 & 7 & 1.7 & 50.0 \\
\hline No information & 0 & - & 12 & 3.0 & 0.0 \\
\hline Type of telephone & \multicolumn{5}{|c|}{$\chi^{2}=282.3(p=0.0001)$} \\
\hline Home line & 75 & 13.1 & 172 & 42.7 & 30.4 \\
\hline Mobile-phone & 16 & 2.8 & 66 & 16.4 & 19.5 \\
\hline Work & 1 & 0.2 & 3 & 0.7 & 25.0 \\
\hline For messages & 10 & 1.7 & 20 & 5.0 & 33.3 \\
\hline More than one & 472 & 82.2 & 99 & 24.6 & 82.7 \\
\hline No phone & 0 & - & 43 & 10.7 & 0.0 \\
\hline Total & 574 & 100.0 & $403^{\star \star}$ & 100.0 & \\
\hline
\end{tabular}

* "No contact" plus "interviews not performed";

** Missing information for 14 cases due to death plus 7 refusals.

Table 2

Outcomes of each attempt at phone contact.

\begin{tabular}{|c|c|c|c|c|c|c|c|c|}
\hline Outcome of attempt & 1 st & 2nd & $3 r d$ & $4^{\text {th }}$ & $5^{\text {th }}$ & $6^{\text {th }}$ & 7th-16th & Total \\
\hline Wrong number & 187 & 47 & 25 & 16 & 4 & 1 & 4 & 284 \\
\hline Number busy & 268 & 190 & 150 & 124 & 63 & 48 & 86 & 929 \\
\hline Not available at that moment & 171 & 81 & 49 & 23 & 10 & 5 & 8 & 347 \\
\hline Did not allow/Did not want & 3 & 3 & 2 & 2 & 1 & 1 & 0 & 12 \\
\hline Interview rescheduled & 12 & 4 & 2 & 1 & - & - & 0 & 19 \\
\hline Incomplete interview & 2 & - & 1 & 1 & 1 & - & 0 & 5 \\
\hline Complete interview & 314 & 129 & 42 & 18 & 20 & 10 & 9 & 542 \\
\hline Complete interview not recorded * & 20 & 6 & 2 & 1 & 3 & - & 0 & 32 \\
\hline Total & 977 & 460 & 273 & 186 & 102 & 65 & 107 & 2,170 \\
\hline
\end{tabular}

* Not recorded at woman's request.

high rate of response to truly represent the studied population, therefore it is important to use recruitment methods that are easily reproducible 8,9,16,17.

In our study the telephone strategy reached more than $60 \%$ of the eligible women, and the interview was carried out with $57.5 \%$ of them.
The studied sample had a high frequency of health problems and the loss of interviews in consequence of death was high, reaching $3.57 \%$ of all contact failures. Other causes to explain the $39.7 \%$ rate of no contact can be attributed to changes in personal identifiers (eg.: changes in address or telephone number). Other studies 
have presented data on losses due to changes in personal identifiers which can reach $76 \%$ of all lost cases 18,19,20. This kind of synonym errors in registries has effects on underestimating the disease incidence among external cohorts linked to the registry 21 .

In addition, time between delivery and interview was the major factor associated with the increase in response rates. Decreasing the time from the hospitalization to the interview increased the response rate from $35.7 \%$ in women with 5 years to $70.9 \%$ in women with less than 1 year. Considering that the refusal rate did not change across time, this finding may be due to the fact that the woman may possibly have changed her telephone number or address since the hospital discharge.

The refusal rates found in the study were very low, indicating that, once tracing the women, the probability of getting the complete interview is high. In fact, most of the interviews were completed at the second attempt. Despite the fact that telephone coverage in Brazil has improved considerably over the last five years all over the country 13 , the possibility of retaining the same number while changing operators has only been from the last year and changes in telephone numbers were frequent before that, which could have interfered with the contact rate. Possibly the rate of success could be higher at a very little extra cost if an introductory postcard would have been mailed for all eligible women before the phone contact 9,16.

According to the number of telephones available for contact, the success rate increased from $30 \%$ to more than $80 \%$ when more than one was available. This rate is close to successful rates found in studies using short-term telephone follow-ups 22 and may be due to an appropriate approach to get information on women's telephone contact.

This was one of the most important findings of this study: when the eligible woman had more than one phone contact there was a significantly higher chance of tracing her compared with only one contact. In the present study, considering the medical records are of good quality, the use of a population selected from a university hospital setting may have contributed to increasing the response rate, but data points to the need to obtain more than one telephone number for contacts in future studies.

Another concern about the health facility influence is the relationship between patients and providers. Tertiary hospitals provide care with higher use of technological equipment, which tends to be considered by population as a "better care" compared with the assistance provided by facilities with less technological resources. This may influence the users' satisfaction towards the facility and therefore, in theory, influence the response rate, but not the trace rate.

The vast majority of women included in this study had their home in Campinas or the surrounding area in the São Paulo State, a developed region in Brazil, with high telephone coverage $-77 \%$ of households with at least one mobile phone 12 . Some authors consider the increasing telephone coverage, especially due to cell phone utilization, a potential benefit for public health research as it makes telephone communication an even greater part of everyday life and makes potential telephone survey respondents even more accessible to researchers 23 . The place of residence (city) did not interfere with the success rates.

Regarding the outcomes of each attempt of phone contact more than half of the calls failed in contacting the women. The study protocol established that the maximum number of negative attempts should be 5 , but they would continue until a successful interview if the woman was traced in one of the first five attempts. With this policy, we were able to have 19 additional interviews performed which represents only $3 \%$ of total interviews. Therefore this should be taken into consideration for future studies in order to avoid time wasting.

Among the total 2,170 phone calls/attempts, there were 574 completed interviews, a proportion of less than four calls for one successful interview. This is an acceptable rate especially when accounting for the cost-efficiency involved in this study. Comparing to face-to-face interviews, the CATI approach may be cheaper, easier to perform and often less intrusive than face-toface interview 23 .

Finally, CATI may be a valuable procedure as an additional tool for gathering information on reproductive health in settings with high telephone coverage with a good cost-benefit relation. Moreover according to this study, the use of the CATI approach is more appropriate in situations with a small time interval between the database registry and the interview and when the database has more than one telephone in the contact list. This data can be useful for researchers as simple data can be systematically added in the hospital admission and afterwards can help to trace people if needed.

However, this method is not free of failure and even in these optimal conditions the no contact rate can be high. In that sense it must be used with precaution in different populations and further studies are needed to clarify the benefits of the method. 


\section{Resumo}

O objetivo foi avaliar a facticidade do telefone como um método de obtenção de informações sobre saúde reprodutiva no Brasil (CATI). Um total de $998 \mathrm{mu}$ lheres elegiveis a um estudo foi selecionado para responder um questionário por telefone com o auxílio de computador e aplicado por entrevistadoras treinadas. Os resultados de cada tentativa de contato estão descritos. A diferença entre os grupos foi avaliada pelo teste qui-quadrado. O contato telefônico foi feito em $60,3 \%$ e 57,5\% completaram a entrevista. A taxa de sucesso melhorou com a diminuição do tempo entre a hospitalização e a entrevista e com a quantidade de números de telefone disponível. Um total de 2.170 chamadas foi feito, de 1 a 16 tentativas por mulher. A maioria das chamadas adicionais foi em razão de a linha estar ocupada ou de a mulher não ter disponibilidade naquele momento. O CATI pode ser um procedimento útil para obtenção de informações em saúde reprodutiva entre mulheres brasileiras, especialmente se dirigido a eventos relativamente recentes e quando mais de um número alternativo de telefone está disponível.

\section{Entrevistas; Telefone; Medicina Reprodutiva}

\section{Contributors}

J. G. Cecatti had the original idea for the study, obtained financial support, supervised the data collection, planned the analysis, coordinated the interpretation of the results and corrected and finalized the article. R. P. S. Camargo and R. C. Pacagnella participated in the analysis and interpretation of the results, wrote the first version of the article and read and approved the final version. T. M. Giavarotti participated in the data collection, was responsible for entering the data into the database, for interpretation of the results, and gave suggestions on the article, and read and approved the final version. J. P. Souza collaborated in all stages of the study, including development of the original idea, implantation of the study, data collection and interpretation of results; as well as reading and approving the final version of the article. M. A. Parpinelli contributed with data interpretation after analysis, gave suggestions on the article and read and approved the final version. $\mathrm{M}$. J. Osis collaborated in the implementation of the study, data collection, supervision of data collection and gave important suggestion for the article, as well as reading and approving the final version.

\section{Acknowledgments}

We gratefully acknowledge the financial support of FAPESP (grant 2007/00290-8).

\section{References}

1. Marcus AC, Crane AL. Telephone surveys in public health research. Med Care 1986; 24:97-112.

2. Corey CR, Freeman HE. Use of telephone interviewing in health care research. Health Serv Res 1990; 25:129-44.

3. Chittleborough CR, Taylor AW, Baum FE, Hiller JE. Non-response to a life course socioeconomic position indicator in surveillance: comparison of telephone and face-to-face modes. BMC Med Res Methodol 2008; 8:54.

4. Lee S, Tsang A, Lau L, Mak A, Ng KL, Chan DM. Concordance between telephone survey classification and face-to-face structured clinical interview in the diagnosis of generalized anxiety disorder in Hong Kong. J Anxiety Disord 2008; 22:1403-11.

5. Lee S, Tsang A, Mak A, Lee A, Lau L, Ng KL. Concordance between telephone survey classification and face-to-face interview diagnosis of one-year major depressive episode in Hong Kong. J Affect Disord 2010; 126:155-60.

6. Sykes W, Collins M. Effects of mode of interview: experiments in the UK. In: Groves RM, Biemer PP, Lyberg LE, editors. Telephone survey methodology. New York: John Wiley and Sons; 2001. p. 301-20.

7. Smith JM, Sullivan SJ, Baxter GD. Telephone focus groups in physiotherapy research: potential uses and recommendations. Physiother Theory Pract 2009; 25:241-56.

8. Thomas R, Purdon S. Telephone methods for social surveys. Social Research Update 1994; (8). http:// sru.soc.surrey.ac.uk/SRU8.html.

9. Smith M, Chey T, Jalaludin B, Salkeld G, Capon T. Increasing response rates in telephone survey: a randomized trial. J Public Health Med 1995; 17:33-8.

10. Banjanovic A. Special report. Towards universal global mobile phone coverage. http://www.eu romonitor.com/Articles.aspx?folder=Special_Re port_Towards_universal_global_mobile_phone_ coverage\&print=true (accessed on 10/Jul/2010).

11. Instituto Brasileiro de Geografia e Estatística. Pesquisa Nacional por Amostra de Domicílios: síntese de indicadores 2003. http://www.ibge.gov.br/ english/presidencia/noticias/noticia_visualiza. php?id_noticia $=226 \& i d \_p a g i n a=1$ (accessed on 10/Jul/2010).

12. Barbosa AF. Survey on the use of information and communication technologies in Brazil: ICT households and ICT enterprises 2008. São Paulo: Comitê Gestor da Internet no Brasil; 2009.

13. Monteiro CA, Moura EC, Jaime PC, Lucca A, Florindo AA, Figueiredo ICR, et al. Monitoramento de fatores de risco para doenças crônicas por entrevistas telefônicas. Rev Saúde Pública 2005; 39:47-57.

14. Souza JP, Cecatti JG, Pacagnella RC, Giavarotti TM, Parpinelli MA, Camargo RS, et al. Development and validation of a questionnaire to identify severe maternal morbidity in epidemiological surveys. Reprod Health 2010; 7:16. 
15. Cooper CP, Jorgensen CM, Merritt TL. Report from the CDC. Telephone focus groups: an emerging method in public health research. J Womens Health (Larchmt) 2003; 12:945-51.

16. Iredell $\mathrm{H}$, Shaw $\mathrm{T}$, Howat $\mathrm{P}$, James R, Granich J. Introductory postcards: do they increase response rate in a telephone survey of older persons? Health Educ Res 2004; 19:159-64.

17. Smyth BP, Darker CD, Donnelly-Swift E, Barry JM, Allwright SP. A telephone survey of parental attitudes and behaviours regarding teenage drinking. BMC Public Health 2010; 10:297.

18. França E, Souza JM, Guimarães MDC, Goulart EMA, Colosimo E, Antunes CMF. Associação entre fatores sócio-econômicos e mortalidade infantil por diarréia, pneumonia e desnutrição em região metropolitana do Sudeste do Brasil: um estudo caso-controle. Cad Saúde Pública 2001; 17:1437-47.
19. Elias MC, Alves A. Medicina não-convencional: prevalência em pacientes oncológicos Rev Bras Cancerol 2002; 48:523-32.

20. Hayakawa LM, Schmidt KT, Rossetto EG, Souza SNDH, Bengozi TM. Incidência de reinternação de prematuros com muito baixo peso nascidos em um hospital universitário. Esc Anna Nery Rev Enferm 2010; 14:324-9.

21. Brenner H, Schmidtmann I, Stegmaier C. Effects of record linkage errors on registry-based follow-up studies. Stat Med 1997; 16:2633-43.

22. Perriera LK, Reeves MF, Chen BA, Hohmann HL, Hayes J, Creinin MD. Feasibility of telephone follow-up after medical abortion. Contraception 2010; 81:143-9.

23. Kempf AM, Remington PL. New challenges for telephone survey research in the twenty-first century. Annu Rev Public Health 2007; 28:113-26.

Submitted on $11 / \mathrm{Jul} / 2010$

Final version resubmitted on 17/Mar/2011

Approved on 07/Apr/2011 